\title{
THE USE OF INFORMATION MODELS TO ENSURE THE MANUFACTURABILITY OF SHIP STRUCTURES AT THE DESIGN STAGES
}

\author{
ВИКОРИСТАННЯ ІНФОРМАЦЙНИХ МОДЕЛЕЙ ДЛЯ ЗАБЕЗПЕЧЕННЯ \\ ТЕХНОЛОГІЧНОСТІ КОНСТРУКЦЙ СУДНА НА ЕТАПАХ ПРОЄКТУВАННЯ
}

\author{
Yurii K. Yahlytskyi \\ yurii.yahlytskyi@nuos.edu.ua \\ ORCID: 0000-0002-4865-0411
}

\author{
Ю. К. Яглицький, \\ канд. техн. наук, доцент»
}

\author{
Admiral Makarov National University of Shipbuilding, Mykolaiv \\ Національний університет кораблебудування імені адмірала Макарова, м. Миколаӥв
}

\begin{abstract}
Currently, the provision of manufacturability is usually attributed to the difficult-to-formalize tasks of technological preparation of production in shipbuilding. Testing a product for manufacturability is a complex task, in solving which the designer and technologist must not only ensure a high technical level and operational qualities of the product being created, but also fully take into account the requirements of production, that is, ensure its production manufacturability. The modern approach to the organization of design and technological design in the conditions of using information models of the product is the need for parallel development of the design, technology and production system. Taking into account that recently the center of gravity of work on ensuring the manufacturability of the ship's hull structures has shifted to the design stages, it is important to provide information support for the processes of managing the manufacturability at these stages. A detailed analysis and an accurate description of the processes occurring at the stages of developing the technical specification, technical proposal (abbreviated ship design), draft and technical projects are required. To do this, you can use such research areas that include the formation of an information model of the object of development and ensuring the production and operational manufacturability of the product design.

The paper considers information models of processes for ensuring the manufacturability of a vessel (ship structures) at the stages of developing a technical task, a technical proposal, draft and technical projects. Information modeling of technological efficiency management processes at the early stages of design with a detailed analysis and accurate description of the processes will allow providing specialists (designers, technologists) with information to create control actions to ensure the necessary level of technological efficiency, increasing the objectivity of the results of its evaluation. It is proposed to use IDEF technology as a modern tool for information modeling and analysis.

Models built using SADT technology allow us to effectively analyze the design of the product, establish the sequence of work, identify factors that affect the qualitative and quantitative assessment of manufacturability.

Key words: manufacturability; information models; ship structures; terms of reference; draft and technical projects of the vessel; IDEF technology; SADT-model.
\end{abstract}

Анотація. Наразі забезпечення технологічності заведено відносити до формалізованих завдань технологічної підготовки виробництва у суднобудуванні. Відпрацювання виробу на технологічність - складне завдання, під час вирішення якого конструктор і технолог повинні не тільки забезпечити високий технічний рівень й експлуатаційні якості створюваного виробу, але й сповна врахувати вимоги виробництва, тобто забезпечити його виробничу технологічність. Сучасний підхід до організації конструкторсько-технологічного проєктування в умовах використання інформаційних моделей виробу полягає в необхідності паралельної розробки конструкції, технології та виробничої системи.

Враховуючи, що останнім часом центр значення робіт із забезпечення технологічності конструкцій корпусу судна зміщується на етапи проєктування, важливо забезпечити інформаційний супровід процесів управління технологічністю на цих етапах. Необхідні детальний аналіз і точний опис процесів, що здійснюються на етапах розробки технічного завдання, технічної пропозиції (скороченого проєкту судна), ескізного та технічного проєктів. Для цього можна використовувати дослідження, які включають формування інформаційної моделі об’єкта розробки та забезпечення виробничої й експлуатаційної технологічності конструкції виробів.

У роботі розглянуто інформаційні моделі процесів забезпечення технологічності судна (суднових конструкцій) на етапах розробки технічного завдання, технічної пропозиції, ескізного та технічного проєктів. Інформаційне 
моделювання процесів управління технологічністю на ранніх етапах проєктування з детальним аналізом і точним описом процесів дозволить забезпечити фахівців (конструкторів, технологів) інформацією для створення керівних впливів щодо забезпечення необхідного рівня технологічності, підвищення об'єктивності результатів іiі оцінки. В якості сучасного інструменту інформаційного моделювання та аналізу пропонується використовувати технологію IDEF.

Моделі, побудовані з використанням технології SADT, дозволяють ефективно проводити аналіз конструкції виробу, встановити послідовність проведення робіт, виявити фактори, що впливають на якісну та кількісну оцінку технологічності.

Ключові слова: технологічність; інформаційні моделі; суднові конструкції; технічне завдання; ескізний і технічний проєкти судна; технологія IDEF; SADT-модель.

\section{ПОСТАНОВКА ЗАДАЧІ}

Сучасне суднобудування характеризується високим рівнем конкуренції, що змушує серійні верфі безперервно вдосконалювати продукцію, яка випускається, підвищувати вимоги до якості виробів, мінімізувати витрати на технічну підготовку і скорочувати цикл виробництва $[1 ; 2]$. Водночас підвищується складність суднових конструкцій і суден загалом із метою зниження матеріаломісткості та маси конструкції виробу. Також удосконалюються методи визначення міцних розмірів суднових корпусів за використання інноваційних матеріалів, покращується технологія й організація побудови суден, все ширше використовуються автоматизовані інформаційні системи під час проєктування та технологічної підготовки виробництва. При цьому однією 3 найважливіших системних властивостей конструкції виробу, що визначають його проєктування, виготовлення і подальшу експлуатацію 3 найкращою якістю та найменшими витратами коштів і часу, є технологічність.

Головними факторами, що виокремлюють вимоги до забезпечення технологічності конструкцій у суднобудуванні, $є$ :

- вид суднової конструкції;

- конструктивна складність конструкції;

- новаційність конструкції;

- характеристика вихідних матеріалів;

- стадія розробки [3; 4].

Творча робота проєктанта-конструктора і технолога в суднобудуванні неможлива без самостійного критичного аналізу наявних конструкцій, без повного й глибокого розуміння всіх вимог, що висуваються до конструкцій і технології їх виготовлення з погляду технологічності.

Останнім часом центр значення робіт із забезпечення технологічності конструкцій зміщується на етапи проєктування, де формується більшість технічних характеристик і закладаються економічні показники конкурентоспроможності та собівартості виробу [5; 6]. Дослідження процесу забезпечення технологічності й на етапах проєктування судна дає можливість для вичерпного і компетентного вирішення цієї проблеми.

\section{МЕТА ДОСЛІДЖЕННЯ}

Все це свідчить про актуальність дослідження та визначає мету, яка полягає у забезпеченні інформаційного супроводу процесів управління технологічністю на ранніх етапах проєктування з детальним аналізом і точним описом процесів.

Відповідно до поставленої мети необхідно вирішити такі, засновані на наукових принципах, завдання:

- провести детальний аналіз і точний опис процесів, які відбуваються на етапах розробки технічного завдання, технічної пропозиції (скороченого проєкту судна), ескізного і технічного проєктів;

- поділити проєктний цикл на етапи, які приблизно відповідають загальноприйнятому поділу процесу проєктування на стадії;

- здійснити системний аналіз наявних процесів на основі їх моделювання та оптимізації для розробки концептуальної моделі перспективних процесів, яка забезпечить однозначність й адаптивність процесів відпрацювання конструкцій судна на технологічність [7; 8];

- створити передумови для проєктування інформаційної системи забезпечення технологічності виробів із електронним обміном даними.

\section{АНАЛІЗ ОСТАННІХ ДОСЛІДЖЕНЬ ТА ПУБЛІКАЦЙ}

Теоретичною базою статті можуть бути наукові роботи в галузі системної організації процесу забезпечення технологічності, нормативно-правова база регістру судноплавства України (Правила класифікації та побудови морських суден), а також дослідження потенційних аспектів проєктування і вибору головних елементів та конструкцій корпусів суден, використання інноваційних технологій проєктування і побудови суден [1; 6]. Питання проєктування конструкцій корпусу суден із забезпеченням оптимальної технологічності висвітлені також у працях О.Л. Васильєва [4; 5].

У дослідженні взято до уваги розробки В.Ю. Угринова, A.M. Попова, Song Yuyiw та D.S. Nau, в яких розкриваються основні питання підвищення ефективності конструкторсько-технологічного проєктування і підготовки виробництва на основі оптимізації 


\section{СУДНОБУДУВАННЯ № 3- 2021}

процесів відпрацювання конструкції деталей та їх складання на технологічність [9-12].

Перевагам використання автоматизованих інформаційних систем, CASE-технологій (засобів автоматизації розробки програм), CALS-технологій (безперервної інформаційної підтримки поставок і життєвого циклу виробів) у процесах структурного моделювання і створення електронних інформаційних моделей виробів суднобудування присвячені наукові праці О.С. Говоркова, О.М. Вендрова, В.В. Павлова, О.М. Галкіної, О.А. Риндіна [13-15].

Питання функціонального моделювання за допомогою IDEF-технології (I-CAM DEFinition), що дозволяє досліджувати структуру, параметри і характеристики виробничо-технічних та організаційно-економічних систем, висвітлені у працях [16-18].

\section{ОСНОВНИЙ МАТЕРІАЛ}

Властивості безлічі конструктивних функціонально і геометрично пов'заних об'єктів судна зумовлюють можливість розгляду його корпусу як складної системи К («Корпус»). Система К є частиною більш складної системи С («Судно»), яка своєю чергою є частиною складнішої системи Ф («Флот») тощо [4; 5]. Кожна система характеризується такими особливостями, як мета, структура і поведінка (рис. 1).

Мета системи $K$ - забезпечення функціонування всієї системи С у важких, нерегулярних умовах експлуатації судна за встановлених термінів служби судна (забезпечення надійності та функціонування судна).

Поведінка системи Кабо процесії функціонування впродовж усього терміну їі служби: від появи технічного завдання до списання і розбирання судна на злам, - це процес проєктування, побудови та експлуатації у складі іншої системи.

Систему $K$ можна охарактеризувати за допомогою різних властивостей, але, як правило, основними
3 них є функціональність, надійність, технологічність, оптимальність, економічність. Конструкції в цій системі розглядаються як об'єкт, котрому властивий набір параметрів. Обираючи відповідні параметри, проєктант у межах, що залежать від нього, організовує систему $K$ і керує поведінкою цієї системи. Властивість технологічності сучасної конструкції корпусу судна має бути враховано на етапі раннього проєктування, щоб передбачити всі співвідношення подальших систем, їх затребуваності та витратності під час виробництва.

Забезпечення технологічності, що характеризує можливість виготовлення й експлуатації судна та його конструкцій за мінімальних витрат сукупної суспільної праці, має виконуватися за неодмінного збереження достатнього рівня надійності і функціональності. Тому в схемі, що наведена на рис. 2 , технологічність представлена як проміжна ціль управління процесом проєктування, що підпорядкована основній меті - надійності [4; 5].

Здійснені впродовж останніх років детальні вивчення процесів виготовлення та експлуатації конструкцій судна дозволили включити в алгоритми проєктування правила та вимоги, які забезпечують виробничу й експлуатаційну технологічність судна та його конструкцій. Таким чином, у проєктуванні з'явився новий напрям, пов'язаний із забезпеченням технологічності завдяки стандартизації, уніфікації та типізації конструкцій.

Враховуючи зміщення в сучасних умовах центру значення робіт із забезпечення технологічності на етапи проєктування судна, важливо забезпечити інформаційний супровід процесів управління технологічністю на цих етапах. Необхідні детальний аналіз і точний опис процесів, які відбуваються на етапах розробки технічного завдання (далі - Т3), технічної пропозиції (скороченого проєкту судна), ескізного і технічного проєктів. Для цього можна

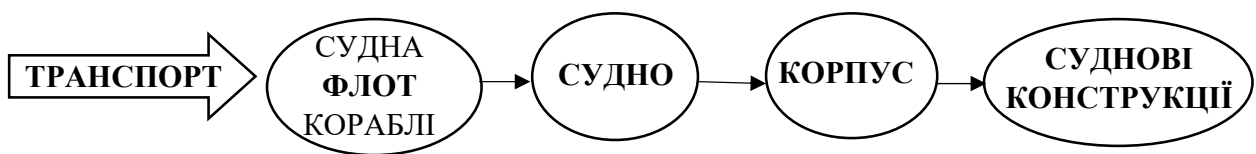

Рис. 1. Іерархія систем

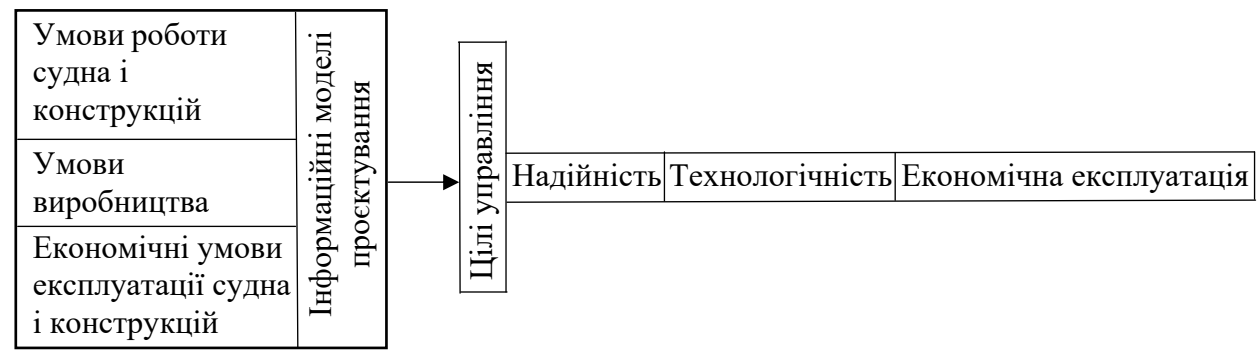

Рис. 2. Місце технологічності в моделях проєктування 
використовувати такі напрями досліджень, як інженерне прогнозування, параметрична оптимізація об'єктів, проєктні розробки, що включають формування інформаційної моделі об'єкта розробки та забезпечення виробничої й експлуатаційної технологічності конструкції виробів. Це дозволить забезпечити фахівців із проєктування суден інформацією для вироблення керівних впливів щодо забезпечення необхідного рівня технологічності та підвищення об'єктивності результатів ії оцінки.

Про порівняну трудомісткість окремих стадій проєктного циклу суден дають уявлення такі дані: технічна пропозиція й ескізний проєкт становлять 5-10\% від обсягу загальних робіт; технічний проєкт $10-15 \%$; робоча конструкторська документація 75-85\% [2; 6]. Із наведеної інформації можна дійти висновку, що на початкові стадії розробки проєктів (технічного та ескізного), які присвячені переважно визначенню основних елементів суден, припадає незначний обсяг загальних робіт. Але від рішень, що приймаються саме на цих стадіях, залежать здебільшого показники ефективності майбутніх суден, тому що вся подальша складна і трудомістка робота є, по суті, деталізацією цих рішень.

Формування технологічності на етапах просктування судна 3 використанням інформаційного моделювання. Наразі системне забезпечення технологічності конструкцій суден включає інформаційний супровід, який створює умови для більшої ефективності робіт, що проводяться фахівцями.

Для ефективного проведення інформаційного моделювання процесів відпрацювання технологічності конструкцій суден проєктний цикл можна поділити на етапи, які приблизно відповідають загальноприйнятому поділу процесу проєктування на стадії:

- розробка ТЗ і структурної схеми судна (розробка Т3 і технічної пропозиції);

- розробка принципових схем на рівні окремих модулів судна (розробка ескізного проєкту);

- розробка конструкцій судна (розробка технічного проєкту та робочої документації).

Проведені дослідження на розглянутих етапах показують наявність активних процесів формування технологічності. Враховуючи це, для більш ефективного управління інформаційними потоками ухвалення проєктно-конструкторських рішень необхідно застосовувати інформаційне моделювання, яке дозволяє представити процеси у вигляді набору стандартних модулів із визначеними правилами функціонування, параметрами вхідних і вихідних даних, керівними даними і механізмами здійснення функцій забезпечення технологічності. Здійснений системний аналіз наявних процесів на основі їх моделювання та оптимізації дозволив розробити концептуальну модель перспективних процесів, яка забезпечила однозначність й адаптивність процесів відпрацювання конструкцій судна на технологічність, а також проєктування інформаційної системи забезпечення технологічності виробів із електронним обміном даними. Під час побудови моделей використовувалися підходи методології функціонального моделювання SADT (Structured Analysis \& Design Technique), які описані в $[16 ; 17]$.

Інформаційна модель забезпечення технологічності на етапі розробки Т3 й архітектурно-конструктивної схеми судна. Процес розробки проєкту судна починається з заявки Замовника, яка містить вихідні основні технікоексплуатаційні вимоги до судна (далі - OTЕВ). До них належать: призначення, умови експлуатації, а також кількість суден, яка необхідна Замовнику. У Т3 на основі вивчення передбачуваного характеру експлуатації судна, узагальнення та аналізу досвіду і тенденцій світового суднобудування уточнюються дані ОТЕВ 3 точки зору найкращих показників технологічності, собівартості, трудомісткості тощо.

На етапі, що розглядається, можливе визначення лише приблизного рівня собівартості за питомими показниками матеріальних і трудових витрат для різних видів суден-прототипів. Вибір судна-прототипу переважно зумовлює межі стандартних та уніфікованих деталей і складальних одиниць, їх спадкоємність. Аналіз умов експлуатації майбутньої конструкції дозволяє сформулювати вимоги до експлуатаційної технологічності, таким чином, зумовлюючи і ступінь технологічності в сфері виробництва, адже ці елементи закладаються саме у виробничу технологічність.

За вибором кожної архітектурно-конструктивної схеми судна лежить складний інженерно-економічний пошук, який дозволяє обрати ії оптимальний варіант із передбачуваною технологічністю.

Інформаційна модель забезпечення технологічності на етапі ескізного просктування. На основі обраного варіанту архітектурно-конструктивної схеми судна, що пройшов експертизу, узгодження та затвердження, розробляється ескізний проєкт, в якому уточнюються отримані на попередній стадії характеристики (за допомогою більш детальних розрахунків і креслень). На етапі ескізного проєктування розробляється конструктивний мідельшпангоут, здійснюються розрахунки щодо міцності судна й елементів корпусних конструкцій, визначаються положення з технології та організації побудови судна, обраховується вартість головного і серійного суден.

На цьому етапі проєктування найбільш технологічною, на думку розробника, буде схема, в якій використані відпрацьовані системні рішення, що не потребують додаткових досліджень. На стадії ескізного проєкту доцільно залучити технологів (виробників) для консультацій щодо прийнятих рішень. Розробник під час проєктування прагне забезпечити, перш за все, визначені технічні параметри, 


\section{ТЕПЛОЕНЕРГЕТИКА № 3 2021}

нехтуючи змістовним аналізом ступеня складності побудови судна як конструкції. Тому технологи, грунтуючись на оцінці технологічних можливостей виробничої бази своєї верфі, вносять позитивні зміни у проєктні рішення, що дозволяє спростити узгодження конструкції з технологією в подальшому, під час освоєння судна $[1 ; 15]$.

На цьому етапі бажано провести розрахунок таких показників технологічності, як трудомісткість виготовлення конструкцій судна, коефіцієнт ефективності взаємозамінності, коефіцієнт стандартизації деталей конструкцій, коефіцієнт застосування складальних одиниць тощо, а також розрахувати наближене значення комплексного показника технологічності конструкцій судна.

Ескізний проєкт повинен містити принципові проєктні та конструктивні рішення за всіма елементами судна й обгрунтування вибору оптимального варіанту для подальшої розробки. Так само, як i технічна пропозиція, ескізний проєкт проходить експертизу, узгодження та затвердження.

Інформаційна модель забезпечення технологічності на етапі розробки технічного проскту i конструкцій судна. На цій стадії проєктування остаточно визначаються всі елементи судна та його технічні й експлуатаційноекономічні характеристики. Як правило, елементи судна і його технічні характеристики, що затверджені в ескізному проєкті, істотно не змінюються. На цій стадії вирішуються переважно конструктивні та технологічні питання: щодо корпусу, енергетичної установки, обладнання та розташування приміщень. При цьому необхідно використовувати технологічні рекомендації з різних процесів виготовлення, зокрема зі складання, для того, щоб розробити таке компонування конструкцій судна, яке забезпечить можливість паралельного складання вузлів конструкцій, конструктивну й технологічну простоту складальних одиниць і деталей, а також виконання інших вимог виробничої та експлуатаційної технологічності.

На цій стадії доцільно продовжувати технікоекономічний аналіз конструкцій створюваних блоків, секцій, вузлів та деталей, основною метою якого є: пошук найбільш економічних конструктивних рішень у напрямах зниження матеріалоємності деталей і складальних одиниць; використання уніфікованих, запозичених і стандартизованих елементів; пошук більш дешевих матеріалів за умови забезпечення визначених характеристик; застосування таких архітектурно-конструктивних рішень, що дозволяють забезпечити значущість судна.

Тісна співпраця проєктантів із виробниками на останніх двох етапах підвищує ефективність робіт із відпрацювання технологічності орієнтовно на 25\%. При цьому визначаються основні дані для організації технологічної підготовки виробництва, з'ясовуються можливості застосування типових технологічних процесів або впровадження нових, проєктується

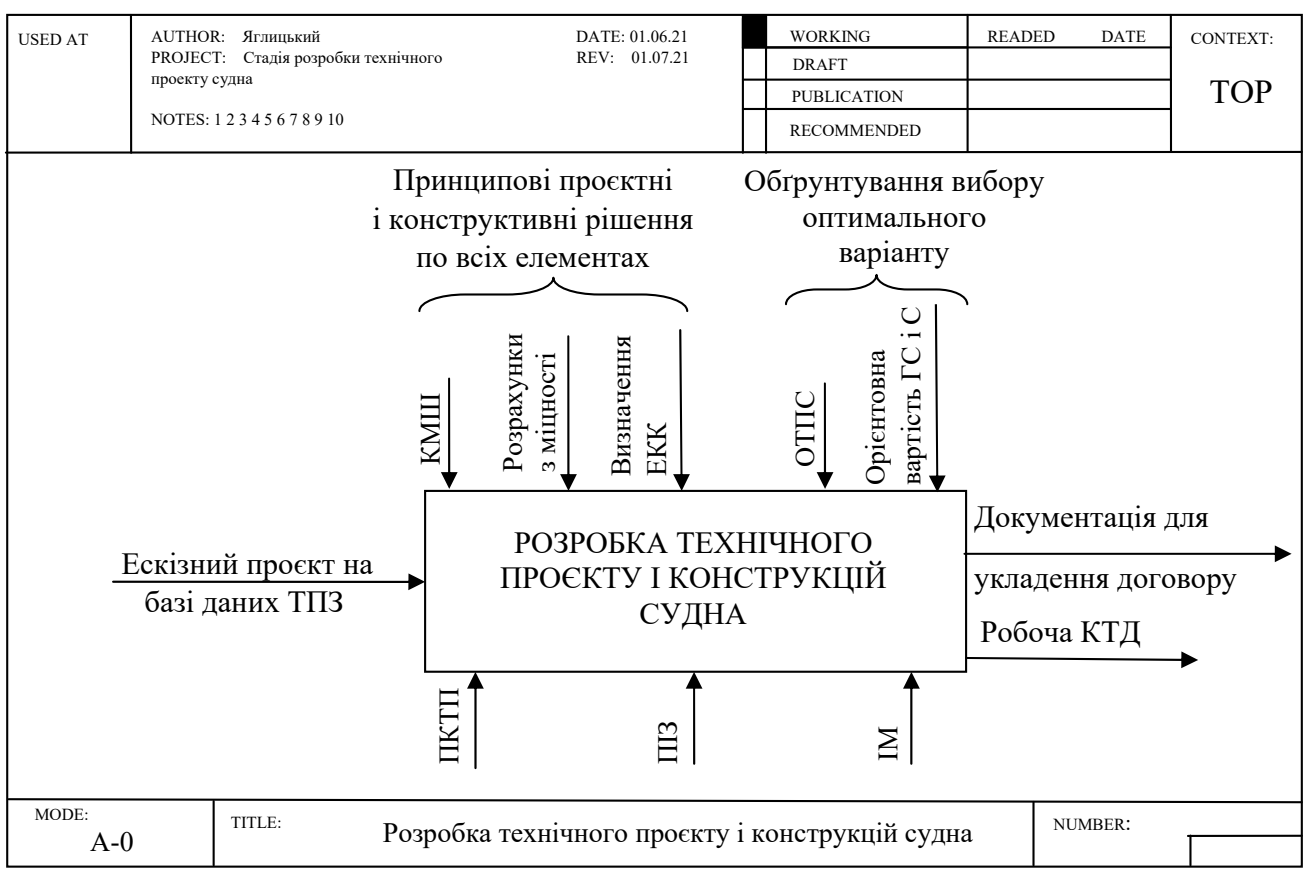

Рис. 3. ТОР-діаграма функціональної моделі розробки технічного проєкту і конструкцій судна

Прийняті скорочення: ТЗП - технічне завдання та технічна пропозиція; КМШ - конструктивний мідель-шпангоут; ЕКК - елементи корпусних конструкцій; ОТПС-організація і технологія побудови судна; ГС - головне судно; СС - серійне судно; ПКТП - проєктно-конструкторськотехнологічний персонал; ПIЗ - програмно-інформаційне забезпечення; IM - інформачійні моделі; КТД - конструкторсько-технологічна документація. 
розробка засобів технічного оснащення для якісного виготовлення суднових конструкцій.

Технічний проєкт проходить експертизу, узгодження, схвалення органами нагляду (Регістром, технічною інспекцією, комітетом 3 екології тощо) i затвердження. На основі матеріалів технічного проєкту розробляється робоча конструкторськотехнологічна документація, яка дозволяє організувати технологічний процес обробки і складання конструктивних елементів судна, монтаж його обладнання й усю послідовність побудови судна. Також на цьому етапі комплектується документація для укладення договору на будівництво судна.

На рис. 3 наведено інформаційну модель процесів відпрацювання технологічності на етапі розробки технічного проєкту і конструкцій судна.

Модель розроблена 3 використанням методу SADT (сукупності правил і процедур для побудови функціональної моделі об'єкта будь-якої предметної галузі). Модель SADT відображає функціональну структуру об'єкта й утворює серію ієрархічних діаграм, які розбивають складний об'єкт на складники у вигляді блоків із супровідною документацією [17; 18$]$.

\section{ВИСНОВКИ}

Проблема якісної оцінки технологічності на ранніх етапах проєктування полягає в тому, щоб, по-перше, зуміти достовірно виміряти інтенсивність факторів, які впливають на технологічність в умовах обмеженості інформації про виріб, i, по-друге, знайти спосіб моделювання системи експертного оцінювання, яка відповідає узагальненому показнику проєктованої техніки.

Проведені дослідження показали, що між наведеними етапами проєктування судна спостерігаються інтенсивні інформаційні потоки, кваліфікована обробка яких сприяє якісному і кількісному аналізу судна та його конструкцій для підвищення рівня технологічності.

В результаті інформаційного моделювання 3 використанням методології функціонального моделювання SADT проведено аналіз процесів забезпечення технологічності конструктивних елементів судна, встановлено послідовність й особливості проведення робіт, виявлено фактори, що впливають на якісну оцінку технологічності та показники кількісної оцінки технологічності конструкції на окремих етапах проєктування судна.

\section{REFERENCES}

[1] Ryzhkov O. S. et al. (2009) Innovatsiini tekhnolohii proektuvannia ta pobudovy suden i zasobiv okeanotekhniky [Innovative technologies of design and construction of ships and means of ocean engineering]. Mykolaiv, $356 \mathrm{p}$. [in Ukrainian]

[2] Logachev S. I., Chugunov V. V. (2009) Mirovoe sudostroenie: sovremennoe sostoyanie i perspektivy razvitiya [World shipbuilding: current state and development prospects]. SPb., 312 p. [in Russian]

[3] Glozman M. K. (1984) Tekhnologichnost konstruktsiy korpusa morskikh sudov. [Manufacturability of ship hull structures]. Leningrad, 296 p. [in Russian]

[4] Vasilev A. L. (1984) Vvedenie v proektirovanie konstruktsiy korpusa sudov. [Introduction to the design of ship hull structures]. Leningrad, 49 p. [in Russian]

[5] Vasilev A. L. (2000) Voprosy proektirovaniya konstruktsiy korpusa sudov. Sistemy nabora perekrytiy korpusa. Vybor shpatsii. [Issues of design of ship hull structures. Hull floor set systems. The choice of space]. SPb., 64 p. [in Russian]

[6] Yegorov G. V. (2004) Osnovy proektirovaniya konstruktsiy korpusov sudov ogranichennykh rayonov plavaniya novogo pokoleniya [Fundamentals of the design of hull structures for ships of limited navigation areas of the new generation]. Zbirnyk naukovykh prats NUK [Proceedings of Admiral Makarov National University of Shipbuilding]. No. 5(398). P. 13-25. [in Russian]

[7] Yaglitskiy Yu. K. (2016) Sistemnaya organizatsiya protsessa obespecheniya tekhnologichnosti [Systematic organization of the process of ensuring manufacturability]. Visnyk Odeskoi derzhavnoi akademii budivnytstva ta arkhitektury [Bulletin of the Odessa State Academy of Civil Engineering and Architecture]. No. 63. P. 266-272. [in Russian]

[8] Govorkov A. C., Akhatov R. Kh. (2011) Analiz tekhnologichnosti izdeliya aviatsionnoy tekhniki na osnove informatsionnogo obraza izdeliya [Analysis of the manufacturability of an aircraft product based on the informational image of the product]. Izvestiya Samarskogo nauchnogo tsentra RAN [Izvestia of the Samara Scientific Center of the RAS]. No. 13(44). P. $285-292$. [in Russian]

[9] Ugrinov V. Yu. (2002) Povyshenie effektivnosti tekhnologicheskoy podgotovki proizvodstva na osnove optimizatsii protsessa otrabotki konstruktsii detaley na tekhnologichnost [Increasing the efficiency of technological preparation of production based on optimizing the process of developing the design of parts for manufacturability]. Instrument $i$ tekhnologii [Tool and technology]. No. 11-12. P. 39-42. [in Russian]

[10] Popov A. M. (2012) Modelirovanie sborochnoy tekhnologichnosti konstruktsii izdeliy v integrirovannykh SAPR [Modeling of assembly manufacturability of product design in an integrated computer-aided design system]. Vestnik DGTU. [Bulletin of DSTU]. No. 1(62). P. 99-108. [in Russian]

[11] Song Y., Cai F. (1999) Concurrent engineering oriented assembly model. Qinghua daxue xuebao. Ziran Kexue bau J.Tsinghua Univ. Science and Tech., no. 39(4). P. 49-52.

[12] Nau D. S., Gupta K. S., Regli W. C. (1997) Automated manufacturability analysis: A survey. Research In Engineering Design. No. 3. P. 168-190. 


\section{СУДНОБУДУВАННЯ №3 2021}

[13] Vendrov A. M. (2005) CASE-tekhnologii. Sovremennye metody i sredstva proektirovaniya informatsionnykh system [CASE technology. Modern methods and tools for designing information systems]. Moskva, 176 p. [in Russian]

[14] Pavlov V. V. (2006) Strukturnoe modelirovanie v CALS-tekhnologiyakh [Structural modeling in CALS technologies]. Moskva, 308 p. [in Russian]

[15] Galkina O. M. et al. (2005) Elektronnaya informatsionnaya model izdeliy sudostroeniya na razlichnykh stadiyakh zhiznennogo tsikla. CADmaster [Electronic information model of shipbuilding products at various stages of the life cycle. CADmaster]. No. 1. P. 27-30. [in Russian]

[16] Marka D. A., MakGouen K. (1993) SADT. Metodologiya strukturnogo analiza i proektirovaniya [SADT. Methodology for structural analysis and design]. Moskva, 239 p. [in Russian]

[17] Cheremnykh S. V., Semenov I. O., Ruchkin V. S. (2008) Modelirovanie i analiz sistem: IDEF-tekhnologii [System Modeling and Analysis: IDEF Technologies: Workshop]. Moskva, 192 p. [in Russian]

[18] Yahlytskyi Yu. K., Kyrychenko K. V. (2018) Funktsionalne modeliuvannia protsesu vyhotovlennia pontona zalizobetonnoho doka [Functional modeling of the process of making a pontoon of a reinforced concrete dock]. Naukovyi visnyk Khersonskoi derzhavnoi morskoi akademii [Scientific Bulletin of the Kherson State Maritime Academy]. No. 1(18). P. 60-66 [in Ukrainian]

\section{СПИСОК ВИКОРИСТАНОЇ ЛІТЕРАТУРИ}

[1] Рижков С. С. та ін. (2009) Інноваційні технології проєктування та побудови суден і засобів океанотехніки. Миколаїв, $356 \mathrm{c}$.

[2] Логачев С. И., Чугунов В. В. (2009) Мировое судостроение: современное состояние и перспективы развития. Санкт-Петербург, 312 с.

[3] Глозман М. К. (1984). Технологичность конструкций корпуса морских судов. Ленинград, 296 с.

[4] Васильев А. Л. (1984) Введение в проектирование конструкций корпуса судов. Ленинград, 49 с.

[5] Васильев А. Л. (2000) Вопросы проектирования конструкций корпуса судов. Системы набора перекрытий корпуса. Выбор шпации. Санкт-Петербург, 64 с.

[6] Егоров Г. В. (2004) Основы проектирования конструкций корпусов судов ограниченных районов плавания нового поколения : сб. наук. труд. НУК. Николаев. № 5(398). С. 13-25.

[7] Яглицкий Ю. К. (2016) Системная организация процесса обеспечения технологичности. Вісник Одеської державної академії будівництва та архітектури. № 63. С. 266-272.

[8] Говорков А. С., Ахатов Р. Х. (2011) Анализ технологичности изделия авиационной техники на основе информационного образа изделия. Известия Самарского научного иентра РАН. № 13(44). С. 285-292.

[9] Угринов В. Ю. (2002) Повышение эффективности технологической подготовки производства на основе оптимизации процесса отработки конструкции деталей на технологичность. Инструмент и технологии. № 11-12. С. $39-42$.

[10] Попов А. М. (2012) Моделирование сборочной технологичности конструкции изделий в интегрированных САПР. Вестник ДГТУ. № 1(62). С. 99-108.

[11] Song Y., Cai F. (1999) Concurrent engineering oriented assembly model. Qinghua daxue xuebao. Ziran Kexue bau J.Tsinghua Univ. Science and Tech., no 39, pp. 49-52.

[12] Nau D. S., Gupta K. S., Regli W. C. (1997) Automated manufacturability analysis: A survey. Research In Engineering Design, no. 9, pp. 168-190.

[13] Вендров А. М. (2005) CASE-технологии. Современные методы и средства проектирования информационных систем. Москва, $176 \mathrm{c.}$

[14] Павлов В. В. (2006) Структурное моделирование в CALS-технологиях. Москва, 308 с.

[15] Галкина О. М. и др. (2005) Электронная информационная модель изделий судостроения на различных стадиях жизненного цикла. CADmaster. № 1. С. 27-30.

[16] Марка Д. А., МакГоуэн К. (1993) SADT. Методология структурного анализа и проектирования. Москва, 239 с.

[17] Черемных С. В., Семенов И. О., Ручкин В. С. (2008) Моделирование и анализ систем: IDEF-технологии. Москва, 192 с.

[18] Яглицький Ю. К., Кириченко К. В. (2018) Функціональне моделювання процесу виготовлення понтона залізобетонного дока. Херсон : Науковий вісник Херсонської державної морської академії. № 1(18). C. 60-66.

(с) Яглицький Ю. К. Дата надходження статті до редакції: 05.08.2021 p. Дата затвердження статті до друку: 20.08.2021 р. 